\title{
THE HISTORY OF PSYCHIATRY
}

enemy bombing during World War II but the minutes of meetings of Boards of Guardians up to the date of their dissolution in 1930 are generally available in public reference libraries or county record offices. The documentation of the conditions of care of lunatics, idiots and imbeciles (to use the terms appropriate to the period under consideration) in Union workhouses would appear to be a necessary supplement to the history of the asylums if the story of the care of the mentally ill and mentally impaired in England in the 19th and 20th centuries is to be fully recorded.

\section{Acknowledgements}

I am obliged for advice in the preparation of this paper to Mr John Briggs and The Horace Barks Library, Hanley, Stoke-on-Trent; the
Public Records Office, Kew kindly allowed me access to relevant documents.

\section{References}

BAKER, D. (1954) Workhouses in the Potterles, p. 15. City of Stoke-on-Trent Historical Buildings Survey.

Lunacy Commissioners' Reports on Visits to the Stoke-uponTrent Workhouse. Public Record Office, MH12, 11471. 11498.

Stoke-upon-Trent Poor Law Unton Minutes, 25, 5 October, 1892.

Scull, A. (1979) Museums of Madness, p. 224. London: Allen Lane.

39th Annual Report of the Commissioners in Lunacy (1885).

Edward Myers, Honorary Research Fellow in Psychiatry, University of Keele, Department of Psychiatry, North Staffordshire Hospital Centre, Thornburrow Drive, Hartshill, Stoke-on-Trent ST4 7QB

\section{One man's meat ...}

To my mind there is nothing quite so dramatic in all clinical psychiatry - perhaps in all clinical medicine - as the swing from mania into depression, or vice versa, of the patient suffering from true, bi-polar manic-depressive psychosis.

Bert was one such case. Then aged 70 , his life for the past 30 years had been laid waste by his chronic illness. Every recommended form of treatment had been tried with no success.

When he was 'high' he was as merry and chirpy as a cricket. There was no job, or jobs, in the ward that he wouldn't have gladly undertaken although there was no guarantee that he would ever complete any one of them. When he plummeted down from his sunlit, affective mountain top to the dark dungeon of despair he was tragically transformed into an inert, near-mute zombie.

That was how I found him when I returned from leave. I knew that to attempt to comfort him in this phase was hopeless but I felt impelled at least to try. "What's the matter Bert?" I asked, trying to be as reassuring as I could. "I'm the wickedest man in the world," he eventually replied with a sigh like a steam engine. "It's the masturbation when I was young, that's what's done it." "But Bert," I interjected, knowing the futility of what I was about to say but was, nevertheless, fool enough to go on and say it, "Ninety five per cent, at least, of all males have at some time masturbated." His tormented features became suffused with anger and his voice took on a matching edge. "You damned doctors are all the same. You just don't understand, none of you. You don't understand why I'm different from all the other 'males', as you call them. I enjoyed it!"

Henry R. Rollin, Emeritus Consultant Psychiatrist 